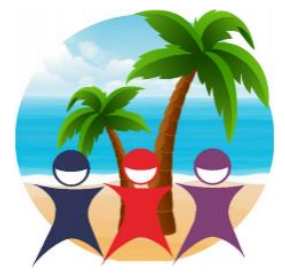

\author{
JOURNAL OF PUBLIC HEALTH FOR TROPICAL AND COASTAL \\ REGION (JPHTCR) \\ Journal homepage: http:/ejournal2.undip.ac.id/index.php/jphtr/index
}

ISSN : 2597-438

\title{
A Study on The Healthy Rental-Housing for College Students according to World Health Organization: Evidence from Surabaya City in Indonesia
}

\author{
Ardiani Putri Rahayu', Sharilla Aryananti Abidin'1, Afifah Faradilla Islami', M. \\ Syafiq Hazlan Ruslan ${ }^{3}$, Kiki Adi Kurnia ${ }^{*}$ \\ ${ }^{1}$ Departement of Marine, Faculty of Fisheries and Marine, Universitas Airlangga, Surabaya, Indonesia \\ 2Department of Chemical Engineering, Faculty of Industrial Technology, Institut Teknologi Bandung, \\ Indonesia \\ ${ }^{3}$ Fakulti Kejuruteraan Kimia, Universiti Teknologi MARA, Shah Alam, Selangor 40450 Malaysia \\ ${ }^{*}$ Corresponding Author. Email: kikiadikurnia@itb.ac.id
}

\begin{abstract}
Introduction: Many college students live far from their parents to study to get a better higher education, so they occupy a rental-housing. However, according to the World Health Organization (WHO), many rental-housings do not meet the health standards. Therefore, this study aims at evaluating the rental-housing quality used by college students in Surabaya, Jawa Timur, Indonesia.

Methods: This type of research is an observational study conducted with a descriptive observational design. The sample in this study was 52 college students who originated from outside Surabaya and currently living in the rental-housing in Mulyorejo, Surabaya, Indonesia.

Results: The results present observational data from 52 student respondents who live in boarding houses, including the overview of boarding houses condition, ventilation and air circulation condition, trash management, clean water and wastewater management, and toilet condition.

Conclusion: Under the circumstance, this study was conducted to assess healthy rentalhousing quality for college students, using the WHO's evaluation indicators. While some college students could afford to stay in proper and healthy rental-housing, some of them still suffer from lousy ventilation, the absence of clean water, and terrible trash management.
\end{abstract}

Keywords: Healthy housing quality, rental-housing, evaluation indicator

Article History: Received: $12^{\text {th }}$ April 2021, Revised: $27^{\text {th }}$ December 2021, Accepted: $29^{\text {th }}$ December 2021

\section{Introduction}

College is the phase where students are presented with many experiences and challenges in the social and environmental and build new networks, behavior, and attitudes due to adapting to a new schedule. During this phase of life, college students have a high risk of having an unhealthy life style due to the negative effect of busy schedules, stress, physical inactivity, and 
poor eating habits. ${ }^{1}$ During study in the university, most students, particularly from the provinces, move from their hometown and live in rental-housing for years. When living alone, college students are required to be independent and responsible in maintaining their own health and hygiene of the rental-housing environment. The boarding house quality selection is also an aspect that can determine the student lifestyle during their stay.

Many studies have evaluated the effect of school quality on housing rents around the world. For example, Clapp et al. (2008) studied the impact of school quality on housing prices using an individual fixed effects model and panel data to control the unobserved neighborhood characteristic. ${ }^{2}$

As a result, the authors showed that parents are willing to pay more, so their children get good quality and healthy rentalhousing in an excellent environment. The environment is a unity of space with all the matter, power, state, and living things, including humans and behavior, which can affect the environment itself, the continuity of life, and welfare of humans and other living things. ${ }^{3}$

As one of the top universities in Indonesia, Universitas Airlangga has received a high number of students from the city of Surabaya and outside the city. Some of their students also come from outside Java Island. The Important problem affecting students' achievement is finding healthy accommodation. It is a first problem college students encounter leaving their cities and moving to another city to get higher education. However, in recent years, due to the increase observed in the number of universities and in the student quotas, yet university' dormitory having fallen short of meeting needs make the problem of accommodation more serious for college students. As a result, the increased number of students outside Surabaya city has led to increased rental-housing, known locally as "kos", to accommodate them. The local residents turn their house into rental-housing with various monthly fees, depending on the location, facility, and quality. While some rental-housing provides a good quality of accommodation for college students, the health quality of some other places is in question. According to World Health Organization (WHO) (2018), health is defined as "a state of complete physical, mental, and social well-being and not merely the absence of disease or infirmity. Environmental is one of the critical factors that can affect health. In this context, a healthy environment could be built by a healthy lifestyle and behavior to enhance life quality. Poor sanitation can affect college student conditions. Scattered garbage around rental-housing and gutters caused unpleasant odors, latrines that were not following health standards, unclean water, and a cramped room can disturb and reduce student concentration of learning and activities in daily life. ${ }^{4}$

This study aims to evaluate college students' rental-housing in Mulyorejo, Surabaya, Indonesia. The evaluation indicators of healthy housing quality, developed by WHO, were used in this study. Because it is easy for college students with wealthy parents to stay in the high-end apartment with good health quality, the results will be biased.

\section{Methods}

The research method used is quantitative with a descriptive observational design. Data collection using Google forms was used to develop the online questionnaire. The Privacy Policy Service evaluates the questionnaire to ensure the anonymity of participants. Furthermore, an email with a survey link was sent to Universitas Airlangga students targeting students living in rental-housing Mulyorejo, Surabaya. This survey is available online from 1-5 March 2021, in Surabaya, Indonesia. Estimated to take about five minutes to complete, no incentives were offered to any respondents. Respondents' answers were only considered if they had answered all the questions. The results are available in Google Sheets which are 
downloaded as excel sheets. The data obtained were analyzed using SPSS Statistics 25.

\section{Results}

This work aimed to evaluate the health level of rental-housing in Surabaya, Indonesia, using several indicators, namely building characteristics, ventilation, clean water, and wastewater management, trash management, and toilet condition. Due to the survey was limited to the college student from the Universitas Airlangga who lives in rental-housing and time constraints to conduct the online questionnaire, only 52 students completed the survey. Most of the respondents were females (90\%). In addition, according to Drissi et al (2020), females are more willing to complete surveys. ${ }^{5}$ Of the participants, $88.5 \%$ were between 20-25 years old. During 2020/2021 academic year, due to the Covid-19 global pandemic, only final-year students are allowed to be on campus, explaining their prevalence in the sample. Meanwhile, students from different years are returned to their hometowns. Furthermore, more than $75 \%$ of the respondents stayed for more than one year in the rental-housing near the Universitas Airlangga. It indicates their satisfaction with the current rental housing. (see Table 1)

Table 1. Respondents' demographic information

\begin{tabular}{llcc}
\hline & & Total & $\%$ \\
\hline \multirow{2}{*}{ Gender } & Female & 47 & 90.4 \\
\cline { 2 - 4 } & Male & 5 & 9.6 \\
\hline \multirow{2}{*}{ Age } & $<20$ years old & 6 & 11.5 \\
\cline { 2 - 4 } & $20-25$ years old & 46 & 88.5 \\
\hline \multirow{3}{*}{$\begin{array}{l}\text { Period of } \\
\text { staying }\end{array}$} & $<6$ months & 6 & 11.5 \\
\cline { 2 - 4 } & 6 month -1 & 8 & 13.5 \\
\cline { 2 - 4 } & years & 15 & 30.8 \\
\cline { 2 - 4 } & $>2$ years & 23 & 44.2 \\
\hline
\end{tabular}

Based on the evaluation indicators of healthy housing quality, the health level of rental-housing was evaluated and analyzed. The evaluation indicators of healthy housing quality were made up of five aspects: building characteristics, ventilation, clean water and wastewater management, trash management, and toilet condition. The building characteristic include the number of occupants, room area, condition of walls, floors, windows, room lighting, areas that are safe from flooding, and the presence of mosquitoes or other insects. Table 2 is an overview of the subject rental-housing characteristic. More than 50\% of respondents stayed in highly dense rentalhousing with more than 11 rooms per house. This result means that more housing intended for a family is turning into rentalhousing to accommodate the high number of college students originally from outside of Surabaya.

The majority of the respondents prefer thick walls/soundproof to give them more privacy and calm during the study. The majority of the respondents also choose to stay in rental-housing located in the region free from the flood (63\%) and mosquito $(42.5 \%)$, as it is known that some area in Surabaya is highly affected by flooding, especially during raining season. Nevertheless, as can be seen from Table 2, approximately $36 \%$ of respondents suffer from flooding. One of the main reasons is that many rental-housing in flooding areas have lower prices than flood-free regions. Thus, in this context, the location of rentahousing plays a significant role in the rent fee.

Apart from the floor, another factor that affects the humidity in the room is ventilation. Less than $55 \%$ of respondents have windows in their room and/or are exposed to direct sunlight (see Table 3). The function of ventilation is to free room air from pathogenic bacteria due to continuous airflow (Notoatmodjo, 2003). The last that relates to the condition of the building is lighting which consists of natural lighting and artificial lighting. Natural lighting relies on the entry of sunlight into the room, and it is highly recommended to use it more during the day (Suyono and Budiman, 2010). It should be stressed that respondents who stay in the rental-housing without proper ventilation (approximately 40\%) suffer from fungus growth in their room. Thus, care must be 
Table 2. Overview of subject rental-housing

\begin{tabular}{|c|c|c|c|}
\hline Characteristic & & Total & $\%$ \\
\hline \multirow{5}{*}{$\begin{array}{l}\text { Number of } \\
\text { rooms }\end{array}$} & $>20$ & 10 & $19.2 \%$ \\
\hline & $16-20$ & 8 & $15.4 \%$ \\
\hline & $11-15$ & 8 & $15.4 \%$ \\
\hline & $6-10$ & 19 & $36.5 \%$ \\
\hline & $1-5$ & 7 & $13.5 \%$ \\
\hline \multirow{5}{*}{ Size of the room } & $<2 \times 2 \mathrm{~m}$ & 3 & $5.7 \%$ \\
\hline & $3 \times 3 \mathrm{~m}$ & 36 & $69.4 \%$ \\
\hline & $4 \times 4 \mathrm{~m}$ & 9 & $17.3 \%$ \\
\hline & $5 \times 5 \mathrm{~m}$ & 3 & $5.7 \%$ \\
\hline & $>5 \times 5 \mathrm{~m}$ & 1 & $1.9 \%$ \\
\hline \multirow{4}{*}{$\begin{array}{l}\text { Thick Wall/ } \\
\text { Soundproof }\end{array}$} & Disagree & 1 & $1.9 \%$ \\
\hline & Neutral & 9 & $17.3 \%$ \\
\hline & Agree & 29 & $55.8 \%$ \\
\hline & $\begin{array}{l}\text { Strongly } \\
\text { agree }\end{array}$ & 13 & $25 \%$ \\
\hline \multirow{4}{*}{$\begin{array}{l}\text { The Floor Made } \\
\text { of Tiles and } \\
\text { Good Condition }\end{array}$} & Disagree & 1 & $1.9 \%$ \\
\hline & Neutral & 2 & $3.8 \%$ \\
\hline & Agree & 25 & $48.1 \%$ \\
\hline & $\begin{array}{l}\text { Strongly } \\
\text { agree }\end{array}$ & 24 & $46.2 \%$ \\
\hline \multicolumn{4}{|l|}{ Location } \\
\hline \multirow{5}{*}{$\begin{array}{l}\text { The rental } \\
\text { housing is safe } \\
\text { from flooding }\end{array}$} & $\begin{array}{l}\text { Strongly } \\
\text { disagree }\end{array}$ & 1 & $1.9 \%$ \\
\hline & Disagree & 5 & $9.6 \%$ \\
\hline & Neutral & 13 & $25 \%$ \\
\hline & Agree & 21 & $40.4 \%$ \\
\hline & $\begin{array}{l}\text { Strongly } \\
\text { agree }\end{array}$ & 12 & $23.1 \%$ \\
\hline \multirow{5}{*}{$\begin{array}{l}\text { There are no } \\
\text { mosquitoes in } \\
\text { the room }\end{array}$} & $\begin{array}{l}\text { Strongly } \\
\text { disagree }\end{array}$ & 5 & $9.6 \%$ \\
\hline & Disagree & 14 & $26.9 \%$ \\
\hline & Neutral & 11 & $21.2 \%$ \\
\hline & Agree & 14 & $26.9 \%$ \\
\hline & $\begin{array}{l}\text { Strongly } \\
\text { agree }\end{array}$ & 8 & $15.4 \%$ \\
\hline
\end{tabular}

taken for college students who are living in the room without proper ventilation as their health might also be affected by the fungus. Based on Housing (Standards For Rented Houses) Regulations 2019 a house to which these Regulations apply (hereinafter referred to as "the house") shall be maintained in a proper state of structural repair.

For the purposes of Regulation 4(1) 'a proper state of structural repair' means sound, internally and externally, with roof, roofing tiles and slates, windows, floors, ceilings, walls, stairs, doors, skirting boards, fascia, tiles on any floor, ceiling and wall, gutters, down pipes, fittings, furnishings, gardens and common areas maintained in good condition and repair and not defective due to dampness or otherwise.
Table 3. Ventilation and air circulation

\begin{tabular}{|c|c|c|c|}
\hline \multicolumn{2}{|l|}{ Characteristic } & Total & $\%$ \\
\hline \multirow{5}{*}{$\begin{array}{l}\text { The Window } \\
\text { Wide is } 10 \% \text { of } \\
\text { the Room Area }\end{array}$} & $\begin{array}{l}\text { Strongly } \\
\text { disagree }\end{array}$ & 3 & $5.7 \%$ \\
\hline & Disagree & 13 & $25 \%$ \\
\hline & Neutral & 8 & $15.4 \%$ \\
\hline & Agree & 24 & $46.2 \%$ \\
\hline & $\begin{array}{l}\text { Strongly } \\
\text { agree }\end{array}$ & 4 & $7.7 \%$ \\
\hline \multirow{5}{*}{$\begin{array}{l}\text { There } \\
\text { Lighting } \\
\text { Sun }\end{array}$} & $\begin{array}{l}\text { Strongly } \\
\text { disagree }\end{array}$ & 4 & $7.7 . \%$ \\
\hline & Disagree & 9 & $17.3 \%$ \\
\hline & Neutral & 9 & $17.3 \%$ \\
\hline & Agree & 20 & $38.5 \%$ \\
\hline & $\begin{array}{l}\text { Strongly } \\
\text { agree }\end{array}$ & 10 & $19.2 \%$ \\
\hline \multirow[t]{5}{*}{$\begin{array}{l}\text { The wall is not } \\
\text { moldy }\end{array}$} & $\begin{array}{l}\text { Strongly } \\
\text { disagree }\end{array}$ & 2 & $3.8 \%$ \\
\hline & Disagree & 10 & $19.2 \%$ \\
\hline & Neutral & 8 & $15.4 \%$ \\
\hline & Agree & 17 & $32.7 \%$ \\
\hline & $\begin{array}{l}\text { Strongly } \\
\text { agree }\end{array}$ & 15 & $28.8 \%$ \\
\hline
\end{tabular}

Water facilities are essential things related to the condition of human skin. Water facilities are divided into two parts: clean water availability and wastewater management. Fortunately, $80 \%$ of the respondents who stay in the rental-housing got clean water from local PDAM (Perusahaan Daerah Air Minum - Regional Water Supply Company). (see Table 4)

The survey results showed that around $80 \%$ of respondents agree that their rental housing has proper wastewater installation made of pipes. However, there is still some rental housing that did not have adequate sewage made of pipes. It showed that the management of the wastewater did not properly throughout.

Trash or residual goods or materials that can cause odor and disease if not properly disposed of in the right place. The scattered garbage may cause the rental housing looks dirty and dull. In addition, trash can cause disease due to the accumulation of microorganisms in a place. Waste is managed properly so as not to cause disease and good to see. According to the survey, rental-housing provides at least one trash bin. However, in high-density rentalhousing, not every room is equipped with a trash bin. It can lead to a buildup of waste 
Table 4. Clean water and wastewater management

\begin{tabular}{|c|c|c|c|}
\hline \multicolumn{4}{|c|}{$\begin{array}{l}\text { Characteristic } \\
\text { Clean water availability }\end{array}$} \\
\hline \multirow{6}{*}{$\begin{array}{l}\text { The Source of } \\
\text { Water from } \\
\text { PDAM }\end{array}$} & Strongly & & \\
\hline & disagree & 1 & $1.9 \%$ \\
\hline & Disagree & 6 & $11.5 \%$ \\
\hline & Neutral & 3 & $5.7 \%$ \\
\hline & Agree & 31 & $59.6 \%$ \\
\hline & $\begin{array}{l}\text { Strongly } \\
\text { agree }\end{array}$ & 11 & $21.2 \%$ \\
\hline \multirow{5}{*}{$\begin{array}{l}\text { The water is } \\
\text { clear and clean } \\
\text { (do not have } \\
\text { any smell) }\end{array}$} & $\begin{array}{l}\text { Strongly } \\
\text { disagree }\end{array}$ & 2 & $3.8 \%$ \\
\hline & Disagree & 4 & $7.8 \%$ \\
\hline & Neutral & 18 & $34.6 \%$ \\
\hline & Agree & 20 & $38.4 \%$ \\
\hline & $\begin{array}{l}\text { Strongly } \\
\text { aqree }\end{array}$ & 8 & $15.4 \%$ \\
\hline \multirow{4}{*}{$\begin{array}{l}\text { Clean water is } \\
\text { always } \\
\text { available }\end{array}$} & Disagree & 5 & $9.6 \%$ \\
\hline & Neutral & 12 & $23.1 \%$ \\
\hline & Agree & 23 & $44.2 \%$ \\
\hline & $\begin{array}{l}\text { Strongly } \\
\text { agree }\end{array}$ & 12 & $23.1 \%$ \\
\hline \multicolumn{4}{|c|}{ Waste Water Disposal Facility } \\
\hline \multirow{3}{*}{$\begin{array}{l}\text { Sewerage } \\
\text { Made of Pipes }\end{array}$} & Neutral & 8 & $15.4 \%$ \\
\hline & Agree & 35 & $69.2 \%$ \\
\hline & $\begin{array}{l}\text { Strongly } \\
\text { agree }\end{array}$ & 8 & $15.4 \%$ \\
\hline \multirow{4}{*}{$\begin{array}{l}\text { Sewage } \\
\text { Disposal in a } \\
\text { Flowing State }\end{array}$} & Disagree & 1 & $2 \%$ \\
\hline & Neutral & 7 & $13.7 \%$ \\
\hline & Agree & 36 & $70.6 \%$ \\
\hline & $\begin{array}{l}\text { Strongly } \\
\text { agree }\end{array}$ & 7 & $13.7 \%$ \\
\hline \multirow{5}{*}{$\begin{array}{l}\text { Sewage } \\
\text { Disposal in a } \\
\text { Flowing State }\end{array}$} & $\begin{array}{l}\text { Strongly } \\
\text { disagree }\end{array}$ & 1 & $2 \%$ \\
\hline & Disagree & 4 & $7.8 \%$ \\
\hline & Neutral & 9 & $17.6 \%$ \\
\hline & Agree & 31 & $60.8 \%$ \\
\hline & $\begin{array}{l}\text { Strongly } \\
\text { agree }\end{array}$ & 6 & $11.8 \%$ \\
\hline
\end{tabular}

that can cause disease. (see Table 5)

Thus, it is highly recommended to have an individual trash bin in every room and to have a regular collection of trash to be dumb at the Tempat Pembuangan Sampah (TPS).The result of the survey showed that respondents agree that their boarding house have toilet (see Table 6). Also, the toilet' floor uses ceramic material. But, in some boarding, there was no adequate ventilation for air circulation. It may cause the presence of insects in the toilet and bad odor. Thus, it is suggested that rental-housing provides a toilet and equips the bathroom with proper ventilation.

Table 5. Trash management

\begin{tabular}{|c|c|c|c|}
\hline Characteristic & & Total & $\%$ \\
\hline \multirow{4}{*}{$\begin{array}{l}\text { There is a trash } \\
\text { bin in the rental- } \\
\text { house }\end{array}$} & Disagree & 1 & $1.9 \%$ \\
\hline & Neutral & 1 & $1.9 \%$ \\
\hline & Agree & 33 & $65.4 \%$ \\
\hline & $\begin{array}{l}\text { Strongly } \\
\text { agree }\end{array}$ & 16 & $30.8 \%$ \\
\hline \multirow{5}{*}{$\begin{array}{l}\text { The number of } \\
\text { trash bins } \\
\text { according to the } \\
\text { room }\end{array}$} & $\begin{array}{l}\text { Strongly } \\
\text { disagree }\end{array}$ & 9 & $17.3 \%$ \\
\hline & Disagree & 14 & $28.8 \%$ \\
\hline & Neutral & 8 & $15.4 \%$ \\
\hline & Agree & 11 & $21.2 \%$ \\
\hline & $\begin{array}{l}\text { Strongly } \\
\text { agree }\end{array}$ & 9 & $17.3 \%$ \\
\hline \multirow[t]{5}{*}{$\begin{array}{l}\text { Trash bin in a } \\
\text { good condition }\end{array}$} & $\begin{array}{l}\text { Strongly } \\
\text { disagree }\end{array}$ & 2 & $4 \%$ \\
\hline & Disagree & 7 & $14 \%$ \\
\hline & Neutral & 9 & $18 \%$ \\
\hline & Agree & 24 & $46 \%$ \\
\hline & $\begin{array}{l}\text { Strongly } \\
\text { agree }\end{array}$ & 9 & $18 \%$ \\
\hline \multirow{4}{*}{$\begin{array}{l}\text { The collected } \\
\text { trash is dumped } \\
\text { at the Tempat } \\
\text { Pembuangan } \\
\text { Sampah (TPS) }\end{array}$} & Disagree & 1 & $1.9 \%$ \\
\hline & Neutral & 11 & $23.1 \%$ \\
\hline & Agree & 20 & $44.2 \%$ \\
\hline & $\begin{array}{l}\text { Strongly } \\
\text { agree }\end{array}$ & 16 & $30.8 \%$ \\
\hline
\end{tabular}

\section{Discussions}

Based on the results, almost $70 \%$ of the respondent prefer a medium size $(3 \mathrm{~m} \mathrm{x}$ $3 \mathrm{~m}$ ) room rather than a bigger space. It might be related to the easiness of cleaning the room. The majority of the respondents $(90 \%)$ prefer housing with the floor is made of tile and in good condition. The type of floor has a role in the disease occurrence process, namely through indoor humidity. ${ }^{6}$ The floor is the wall covering the lower part of the room. Based on Housing (Standards For Rented Houses) Regulations 2019 "habitable room" means a room used for living or sleeping purposes but does not include a kitchen having a floor area of less than 6.5 square meters.

The house floor construction must be watertight and always dry so that it is easy to clean from dirt and dust. In addition, to avoid rising soil which can cause increased humidity in the room to prevent water from entering the house, the floor of the house should be raised $20 \mathrm{~cm}$ above the ground. 
Table 6. Toilet Condition

\begin{tabular}{|c|c|c|c|}
\hline Characteristic & & Total & $\%$ \\
\hline \multirow{3}{*}{$\begin{array}{l}\text { At least one toilet } \\
\text { is available in the } \\
\text { rental-housing }\end{array}$} & Neutral & 1 & $1.9 \%$ \\
\hline & Agree & 26 & $51 \%$ \\
\hline & $\begin{array}{l}\text { Strongly } \\
\text { agree }\end{array}$ & 24 & $47.1 \%$ \\
\hline \multirow{5}{*}{$\begin{array}{l}\text { A toilet } \\
\text { available } \\
\text { every room }\end{array}$} & Strongly & 9 & $173 \%$ \\
\hline & Disagree & 31 & $59.6 \%$ \\
\hline & Neutral & 4 & $7.7 \%$ \\
\hline & Agree & 4 & $7.7 \%$ \\
\hline & $\begin{array}{l}\text { Strongly } \\
\text { agree }\end{array}$ & 4 & $7.7 \%$ \\
\hline \multirow{3}{*}{$\begin{array}{l}\text { The toilet' floor } \\
\text { uses ceramics }\end{array}$} & Neutral & 1 & $1.9 \%$ \\
\hline & Agree & 31 & $59.6 \%$ \\
\hline & $\begin{array}{l}\text { Strongly } \\
\text { agree }\end{array}$ & 20 & $38.5 \%$ \\
\hline \multirow{5}{*}{$\begin{array}{l}\text { There } \\
\text { insect } \\
\text { toilet }\end{array}$} & $\begin{array}{l}\text { Strongly } \\
\text { disagree }\end{array}$ & 3 & $5.8 \%$ \\
\hline & Disagree & 8 & $15.4 \%$ \\
\hline & Neutral & 9 & $17.3 \%$ \\
\hline & Agree & 24 & $46.2 \%$ \\
\hline & $\begin{array}{l}\text { Strongly } \\
\text { agree }\end{array}$ & 8 & $15.4 \%$ \\
\hline \multirow[t]{5}{*}{$\begin{array}{l}\text { The toilet is easy } \\
\text { to clean }\end{array}$} & $\begin{array}{l}\text { Strongly } \\
\text { disagree }\end{array}$ & 1 & $1.9 \%$ \\
\hline & Disagree & 4 & $7.8 \%$ \\
\hline & Neutral & 6 & $11.8 \%$ \\
\hline & Agree & 29 & $56.9 \%$ \\
\hline & $\begin{array}{l}\text { Strongly } \\
\text { agree }\end{array}$ & 11 & $21.6 \%$ \\
\hline \multirow{4}{*}{$\begin{array}{l}\text { There is a } \\
\text { ventilation in the } \\
\text { toilet }\end{array}$} & $\begin{array}{l}\text { Strongly } \\
\text { disagree }\end{array}$ & 4 & $7.7 \%$ \\
\hline & Disagree & 7 & $13.5 \%$ \\
\hline & Neutral & 23 & $44.2 \%$ \\
\hline & $\begin{array}{l}\text { Strongly } \\
\text { agree }\end{array}$ & 18 & $34.6 \%$ \\
\hline \multirow{5}{*}{$\begin{array}{l}\text { The toilet does } \\
\text { not have bad } \\
\text { odor }\end{array}$} & $\begin{array}{l}\text { Strongly } \\
\text { disagree }\end{array}$ & 1 & $1.9 \%$ \\
\hline & Disagree & 5 & $9.6 \%$ \\
\hline & Neutral & 10 & $19.2 \%$ \\
\hline & Agree & 28 & $53.8 \%$ \\
\hline & $\begin{array}{l}\text { Strongly } \\
\text { agree }\end{array}$ & 8 & $15.4 \%$ \\
\hline
\end{tabular}

The condition of the floor of the house needs to be made of materials that are impervious to water so that it does not become damp and always wet, such as tiles, cement, and ceramics. Floors that do not meet the requirements can be used as a place to live and breed insects and bacteria. This, in general, much rental-housing building occupied by college students is in good condition.

Apart from the floor, another factor that affects the humidity in the room is ventilation.
Less than $55 \%$ of respondents have windows in their room and/or are exposed to direct sunlight. The function of ventilation is to free room air from pathogenic bacteria due to continuous airflow. The last that relates to the condition of the building is lighting which consists of natural lighting and artificial lighting. Natural lighting relies on the entry of sunlight into the room, and it is highly recommended to use it more during the day). ${ }^{6}$ It should be stressed that respondents who stay in the rental-housing without proper ventilation (approximately 40\%) suffer from fungus growth in their room. Thus, care must be taken for college students who are living in the room without proper ventilation as their health might also be affected by the fungus. Based on Housing (Standards For Rented Houses) Regulations 2019, A house to which these Regulations apply (hereinafter referred to as "the house") shall be maintained in a proper state of structural repair. For the purposes of Regulation 4(1) 'a proper state of structural repair' means sound, internally and externally, with roof, roofing tiles and slates, windows, floors, ceilings, walls, stairs, doors, skirting boards, fascia, tiles on any floor, ceiling and wall, gutters, down pipes, fittings, furnishings, gardens and common areas maintained in good condition and repair and not defective due to dampness or otherwise.

Water is essential thing for health, not only for production but also for domestic consumption and utilization. Increased infectious diseases that can be deadly or detrimental to health are transmitted through contaminated water. Some water-related diseases are contagious. These diseases are generally classified according to various environmental aspects that humans can intervene. Based On Housing (Standards For Rented Houses) Regulations 2019 There shall be provided within the same habitable area of the house, for the exclusive use of the house: (a) A water closet, with dedicated wash hand basin adjacent there to with a continuous supply of cold water and a facility for the piped supply of hot water, and (b) A fixed bath or shower with continuous supply of cold water and a facility for the piped 
supply of hot water. Through the provision of clean water, both in terms of quality and quantity in an area, it is hoped that the spread of infectious diseases can be minimized. Lack of clean water, especially for maintaining personal hygiene, can cause various skin diseases due to fungi and bacteria. ${ }^{7}$ It is, however, approximately $10 \%$ of the respondent could not get a proper clean water supply. Therefore, the rentalhousing should install an appropriate device to get clean water from PDAM.

In regard to wastewater management, it is the remaining water that is disposed of and comes from households that can contain substances that are harmful to human health. ${ }^{8}$ More than $80 \%$ of the respondent have their rental-housing installed with proper wastewater treatment. Sewer condition that does not meet the requirements has a harmful impact, such as a medium for reproducing the seed spreader vector disease. Wastewater can cause an unpleasant odor, an unpleasant view for families, and incidences of diarrheal disease. $^{3}$ Healthy wastewater disposal facilities must meet the requirements of not polluting clean water sources, not causing stagnant water, not causing odors, and not causing shelter and breeding grounds for mosquitoes o other insects. ${ }^{9}$

\section{Conclusion}

This study was conducted to assess the quality of healthy rental housing for students using WHO evaluation indicators. While some students are able to live in rental-housing that is proper, healthy and has adequate facilities, some of them still suffer from poor ventilation, lack of clean water, and poor waste management that affect student health. Further research that can be done is the effect of rental-housing conditions on student health, such as diseases that can be suffered by students and students' mental health conditions.

\section{Acknowledgment}

None

\section{Funding}

Not applicable

\section{Ethics approval}

Not applicable

\section{References}

1. Almutairi, K. M., Alonazi, W. B., Vinluan, J. M., Almigbal, T. H., Batais, M. A., Alodhayani, A. A., et al. Health promoting lifestyle of university students in Saudi Arabia: a crosssectional assessment. BMC public health. 2018;18(1).1-10.

2. Anna, P. Science Technology Society. 2005. Bandung: PT Remaja.

3. Clapp, J. M., Nanda, A., \& Ross, S. L. Which school attributes matter? The influence of school district performance and demographic composition on property values. Journal of urban Economics, 2008;63(2): 451-466.

4. Anhar, A. Study of environmental Sanitation of Student in Mangasa, Makassar City in 2010 (Doctoral dissertation, Universitas Islam Negeri Alauddin Makassar). Makassar: Universitas Alauddin Makassar; 2010.

5. Drissi, N., Alhmoudi, A., Al Nuaimi, H., Alkhyeli, M., Alsalami, S., \& Ouhbi, S. Investigating the impact of COVID-19 lockdown on the psychological health of university students and their attitudes toward mobile mental health solutions: two-part questionnaire study. JMIR formative research, (2020);4(10): e19876.

6. Suyono and Budiman. Public Health Sciences in the Context of Environmental Health. Jakarta: EGC; 2010.

7. Notobroto. Environmental sanitation factors that play a role in the prevalence of scabies. Surabaya: Faculty of Public Health Universitas Airlangga; 2005.

8. Notoadmodjo, S. Public Health Sciences. Jakarta: PT. Rineka Cipta; 2003.

9. Anwar, D. Basic of Environment Health. Makassar: FKM Unhas; 2005. 